\title{
Relationship between Socio-Economic Profile and Extent of Media Use by Woman Members of Panchayat Raj Institutions (PRIs)
}

\author{
S. Kanase Pallavi ${ }^{1}$, R. B. Kalamkar ${ }^{2 *}$, S. S. Shende ${ }^{2}$ and K. V. Chorge ${ }^{3}$ \\ ${ }^{1}$ Department of Extension Education, RCSMC College of ABM, Sangli, India \\ ${ }^{2}$ Department of Extension Education, College of Agriculture, Baramati, India \\ ${ }^{2}$ VNMKV, Parbhani, India \\ ${ }^{3}$ Department of Extension Education, College of Agriculture, \\ Dr Balasaheb Sawant Konkan Krishi Vidyapeeth, Dapoli, 415712, India \\ *Corresponding author
}

\section{A B S T R A C T}

\begin{tabular}{|c|}
\hline Keywords \\
\hline $\begin{array}{l}\text { Panchayat Raj } \\
\text { Institutions } \\
\text { (PRIs), Extent of } \\
\text { media use }\end{array}$ \\
\hline Article Info \\
\hline $\begin{array}{l}\text { Accepted: } \\
\text { 22 June } 2020 \\
\text { Available Online: } \\
10 \text { July } 2020\end{array}$ \\
\hline
\end{tabular}

The study was conducted in Ratnagiri district. In all, 112 PRI woman members were selected from four Panchayat Samities, five Grampanchayats from each selected Panchayat Samiti and Ratnagiri Zilha Parishad on the basis of maximum number of woman members. The personal and socio-economic characteristics namely age, education, land holding, annual income, major occupation, official position, tenure of work, cosmopoliteness, extension contact, organizational participation, interest in public work and political awareness of the respondents were considered as the independent variables. They were interviewed with the help of a specially designed interview schedule. An interview schedule was prepared in Marathi to collect the information in line with the objective of the study. Collected data were processed and tabulated by using simple frequency, and the parameters like percentage , mean and standard deviation, as well as, the correlation and regression coefficient were used Majority of the respondents had 'medium' extent of media use and utilization. The characteristics namely, education, land holding, annual income, tenure of work, cosmopoliteness, extension contact, organizational participation, interest in public work and political awareness were having positive and significant relationship with their extent of media use.

\section{Introduction}

After seventy two years of independence, rural women are still ignorant about many activities of their day to day life. As per the $73^{\text {rd }}$ constitutional amendment, 33 per cent seats are reserved for women in Panchayat Raj Institution. The Ashok Mehta Committee
Report (1978) stressed the importance of role of women in decision making in development. In fact, for the first time, the Committee with all the women member of the zillha parishad represented on it, so as to enable the women to make the decisions themselves on priorities and choices in welfare and development programmes meant for women and children. 
Many developmental programmes are being launched by government and non-government organization for rural people. Hence, there is an urgent need to diffuse the useful technical know-how among PRIs woman members to improve socio-economic status and increase their knowledge level.

Members elected to the various PRIs are important, not only because they are politically influential, but also because they are direct carriers of knowledge of various agricultural and rural development programmes and modern agricultural techniques to rural community.

Any community has a tendency to follow their leaders. At grass root level, the three tier system of Panchayat Raj Institution is the foremost system of our republic government from grampanchayat at village level, panchayat samiti at taluka level and zilla parishad at district level. The persons elected as members of these institutions play a very important role in the process of rural development.

\section{Statement of the problem}

The Panchayat Raj has come into existence with the sole aim of decentralization of governmental power for the welfare of the rural people. After independence, the Panchayat Raj has become a back-bone of Indian democracy. Indian women were often 'physically visible' but conceptually 'invisible' and were remained marginalized. But now a days, situation is changing; they are coming in each sector with men and thus in administration also.

Union Cabinet of Government of India on 27 August 2009, approved 50 per cent reservation for women in PRIs. The Indian states those have already implemented 50 per cent reservation are Madhya Pradesh, Bihar,
Uttarakhand and Himachal Pradesh. Also on 25 of November 2011, the states of Andhra Pradesh, Chhatisgarh, Jharkhand, Kerala, Maharashtra, Orissa, Rajasthan and Tripura are also having 50 per cent reservation for women in Panchayat Raj.

The women Panchayat Chairpersons in many places are doing well, there is only need to disseminate information regarding various aspects of rural development. This can be only possible with help of communication media. Therefore, the present study was conducted with objective, to ascertain relationship between socio-economic profile and extent of media use by woman members of PRIs for seeking information on rural development.

\section{Limitations of the study}

Due to limitation of time and resources, the study was restricted to limited aspects. Also, the data were collected from one Zilla Parishad, four Panchayat Samities and five Grampanchayats from each selected tahsils in Ratnagiri district. Hence, findings cannot be generalized beyond the limits of the area of the study. However, the findings may become applicable in the areas where similar conditions exist.

\section{Area of study}

The study was conducted in the Ratnagiri district of Konkan region having geographical area 8,208 sq.km. There are nine tahsils, in the district. The study was carried out in four tahsils namely, Ratnagiri, Chiplun, Khed and Dapoli.

\section{Tools and techniques of data collection}

An interview schedule was prepared in Marathi to collect the information in line with the objectives of the study. 


\section{Statistical analysis}

The data were processed and tabulated by using simple frequency, and the parameters like percentage, mean and standard deviation, as well as, the correlation and regression coefficient were used.

\section{Results and Discussion}

Relationship between socio-economic profile and extent of media use by woman members of PRIs for seeking information on rural development

Correlation coefficients (r) were worked out to ascertain the relationship between the selected socio-economic characteristics and extent of media used by the woman members of PRIs. The relationships observed are shown in Table 1.

\section{Age and extent of media use}

It is observed from Table 1 that association between age $\left(\mathrm{X}_{1}\right)$ of the respondents and extent of media use (Y) was positive but nonsignificant. It means, there was no statistically significant influence of age on the extent of media used by the respondents.

The findings are somewhat similar to the findings of Gonjari (1996), and dissimilar with the findings of Kumar and Philip (2002).

\section{Education and extent of media use}

The data from the Table1 visualize that the relationship between education of the respondents $\left(\mathrm{X}_{2}\right)$ and extent of media use $(\mathrm{Y})$ was positive and significant at 0.05 level of probability.

This indicated that the education of the respondents had remarkable influence on their extent of media use. Education helps an individual in enriching knowledge about various fields by availing access to various media or sources of information. This was proved in the present investigation, where as, the educational level attained by PRI woman members increased, their extent of media use also increased significantly.

The findings are similar to findings of Shridhar (1978) and Kumar and Philip (2002).

\section{Land holding and extent of media use}

It is clear from Table1 that the association between land holding $\left(\mathrm{X}_{3}\right)$ and extent of media use $(\mathrm{Y})$ of the respondents was positive and significant. It indicated that as the land holding of the respondent's family increased their extent of media use was increased and vice versa.

The bigger land holding might have been helping the respondents to have better income and thereby better access to different information media.

The findings are similar to the findings of Kumar and Philip(2002) and dissimilar with the findings of Gonjari (1996).

\section{Annual income and extent of media use}

It is revealed from Table 1 that the relationship between annual income $\left(\mathrm{X}_{4}\right)$ and extent of media use $(\mathrm{Y})$ of the respondents was positive and significant. Accordingly, the findings indicate that annual income had substantial impact on of the extent of media use by PRI woman members.

The higher income may help to contact, own and /or have easy access to different information media. This might be the reason behind the results of this investigation. The findings are dissimilar with findings of Gonjari (1996). 


\section{Major occupation and extent of media use}

It is noticed from Table1 that there was positive and non-significant association between major occupation $\left(\mathrm{X}_{5}\right)$ and extent of media use (Y) by the respondents. It can be said that major occupation of family of the respondents had no influence on the extent of media use by PRI woman member.

In other words, it can be said that the respondents from all the occupational groups were more or less equally distributed in all media use categories. The findings are similar to findings of Gonjari (1996).

\section{Official position and extent of media use}

The data presented in Table1 indicated that there was positive and non-significant association between official position $\left(\mathrm{X}_{6}\right)$ and the extent of media use by PRI woman members $(\mathrm{Y})$.

It was assumed that higher leadership position would lead to better use of information media. However, this hypothesis didnot hold true in this investigation. Thus, it can be concluded that official position of respondents does not have statistically significant impact on the extent of media use by PRI woman members.

\section{Tenure of work and extent of media use}

The data presented in Table1 indicated that there was a positive significant association between tenure of work and the extent of media use (Y) by the respondents at 0.05 level of probability. It means, that increase in tenure of work that is membership in PRIs increased the extent of media use by PRI woman members and vice versa.

This may be due to the fact that the PRI members have to use more number of sources of information for effective working as a PRI member. Those who are experienced more might have been using more sources more frequently than those who are less experienced.

\section{Cosmopoliteness and extent of media use}

It is observed from Table 1 that the association between cosmopoliteness $\left(\mathrm{X}_{8}\right)$ and the extent of media use (Y) of the respondents at level of probability 0.05 was positive and significant.

It can be concluded that cosmopoliteness of the respondents had considerable influence on their extent of media use. The better orientation and exposure to social system outside to locality helps to get better awareness and understanding importance of information media. This may be the reason for the observation in the present investigation.

\section{Extension contact and extent of media use}

It is seen from Table1 that there was a positive and significant association between extension contact $\left(\mathrm{X}_{9}\right)$ and the extent of media use $(\mathrm{Y})$ of the respondents at 0.05 level of probability. It indicated that the extent of media use and utilization increases with increase in extension contact.

The probable reason behind this might be that through such contacts, respondents become aware about many government schemes and development programmes. The findings are dissimilar to the findings of Gonjari (1996).

\section{Organizational participation and extent of media use}

The results presented in Table1 showed that there was positive and significant association between organizational participation $\left(\mathrm{X}_{10}\right)$ and the extent of media use (Y) of the respondents at 0.05 level of probability. 
Table.1 Relationship of the socio-economic profile $\left(\mathrm{X}_{\mathrm{i}}\right)$ of woman members of PRIs with extent of media used by them (Y)

\begin{tabular}{|c|c|c|c|}
\hline $\begin{array}{l}\text { Sl. } \\
\text { No. }\end{array}$ & Characteristics & $\begin{array}{l}\text { Variable } \\
\text { code }\end{array}$ & $\begin{array}{l}\text { Correlation } \\
\text { coefficient (r) }\end{array}$ \\
\hline 1. & Age & $\mathrm{X}_{1}$ & 0.18198NS \\
\hline 2. & Education & $\mathrm{X}_{2}$ & $0.20054 *$ \\
\hline 3. & Land holding & $\mathrm{X}_{3}$ & $0.314809 *$ \\
\hline 4. & Annual income & $\mathrm{X}_{4}$ & 0.447854* \\
\hline 5. & Major occupation & $\mathrm{X}_{5}$ & $0.1156231 N S$ \\
\hline 6. & Official position & $\mathrm{X}_{6}$ & 0.13838 NS \\
\hline 7. & Tenure of work & $\mathrm{X}_{7}$ & $0.442639 *$ \\
\hline 8. & Cosmopoliteness & $\mathrm{X}_{8}$ & $0.414987 *$ \\
\hline 9. & Extension contact & $\mathrm{X}_{9}$ & $0.550478 *$ \\
\hline 10. & Organizational participation & $\mathrm{X}_{10}$ & $0.200713 *$ \\
\hline 11. & Interest in public work & $\mathrm{X}_{11}$ & $0.201443 *$ \\
\hline 12. & Political awareness & $X_{12}$ & $0.478435 *$ \\
\hline
\end{tabular}

Table.2 Regression co-efficient between the selected traits of the PRI woman members and extent of media used by them

\begin{tabular}{|l|l|l|l|l|}
\hline $\begin{array}{l}\text { Sl. } \\
\text { No. }\end{array}$ & Characteristics & $\begin{array}{l}\text { Variable } \\
\text { code }\end{array}$ & $\begin{array}{l}\text { Regression } \\
\text { coefficient }\end{array}$ & 't' Value \\
\hline $\mathbf{1 .}$ & Age & $\mathrm{X}_{1}$ & 0.044283 & $\mathbf{0 . 5 0 1 4 9}$ \\
\hline $\mathbf{2 .}$ & Education & $\mathrm{X}_{2}$ & -0.357781 & $\mathbf{- 1 . 4 8 4 0 0 5}$ \\
\hline $\mathbf{3 .}$ & Land holding & $\mathrm{X}_{3}$ & -0.146318 & $\mathbf{- 0 . 1 0 6 6 9 1}$ \\
\hline $\mathbf{4 .}$ & Annual income & $\mathrm{X}_{4}$ & 7.983820 & $\mathbf{0 . 8 9 5 4 0 7}$ \\
\hline $\mathbf{5 .}$ & Major occupation & $\mathrm{X}_{5}$ & -0.247762 & $\mathbf{- 0 . 3 8 3 0 2 3}$ \\
\hline $\mathbf{6 .}$ & Official position & $\mathrm{X}_{6}$ & 0.753792 & $\mathbf{0 . 6 5 3 9 8 1}$ \\
\hline $\mathbf{7 .}$ & Tenure of work & $\mathrm{X}_{7}$ & 0.055599 & $\mathbf{1 . 8 8 7 8 6 9}$ \\
\hline $\mathbf{8 .}$ & Cosmopoliteness & $\mathrm{X}_{8}$ & 0.515066 & $\mathbf{0 . 7 7 5 4 1 4}$ \\
\hline $\mathbf{9 .}$ & Extension contact & $\mathrm{X}_{9}$ & $1.613632 *$ & $\mathbf{3 . 5 4 4 3 1 1}$ \\
\hline $\mathbf{1 0 .}$ & Organizational participation & $\mathrm{X}_{10}$ & $0.756105 *$ & $\mathbf{2 . 4 5 5 1 8 4}$ \\
\hline $\mathbf{1 1 .}$ & Interest in public work & $\mathrm{X}_{11}$ & -0.506613 & $\mathbf{- 1 . 3 5 6 8 5 5}$ \\
\hline $\mathbf{1 2 .}$ & Political awareness & $\mathrm{X}_{12}$ & $\mathbf{0 . 8 1 2 6 3 4}$ & $\mathbf{2 . 9 0 3 9 0 8}$ \\
\hline $\mathrm{R}^{2}=0.491723 ;$ & 'F' Value $=7.981331 ;$ & $*$ Significant at 0.05 level & \\
\hline
\end{tabular}

It means that increase in organizational participation of PRI woman member leads to remarkable increase in their media use.

This may be because such organizations are best forums for communicating various type of information like agricultural and allied enterprises, as well as about the schemes for development of these sectors which are major component of rural development.

The findings are similar with the findings of Kumar and Philip (2002) and dissimilar with the findings of Gonjari (1996). 


\section{Interest in public work and extent of media use}

It is seen from Table1 that there was a positive and significant association between interest in public work $\left(\mathrm{X}_{11}\right)$ and the extent of media use $(Y)$ of the respondents at 0.05 level of probability.

It means, better inclination for rural development causes increase in information seeking behavior of respondents which leads to increase in the extent of media use.

\section{Political awareness and extent of media use}

Positive and significant association was found between political awareness $\left(\mathrm{X}_{12}\right)$ and the extent of media use (Y) of the respondents at 0.05 level of probability.

It indicated that more the political awareness, better was the media utilization by the respondents. The political awareness is essential for development. This might have helped in getting such result.

\section{Regression co-efficient $\left(\mathbf{R}^{2}\right)$}

The data with regard to relationship between independent variables and dependent variable were subjected to regression analysis, so as to know the extent of contribution of independent variables in the dependent variable. The regression coefficients and ' $t$ ' values of the selected variables are shown in Table 2.

The data in Table 2 reveals that, at overall level, regression coefficients of the characteristics of the respondents namely extension contact $\left(\mathrm{X}_{9}\right)$, organizational participation $\left(\mathrm{X}_{10}\right)$ and political awareness $(\mathrm{X}$ 12) were significantly contributing to the extent of media used by PRIs woman members at 0.05 per cent level of probability.
Contribution of remaining nine characteristics was non-significant.

It means that extension contact, organizational participation and political awareness were the factors contributing most in determining the extent of media use of woman members of PRIs. As the extension contact, organizational participation and political awareness increased by one score, the extent of media use by the woman members of PRIs increased by $1.61,0.7561$ and 0.812634 , respectively. The value of multiple determination $\left(\mathrm{R}^{2}\right)$ was 0.4917 indicating, thereby, that at overall level, 49.17 per cent variation in the extent of media use by the woman members of PRIs was explained by the twelve independent variables under the study.

The study revealed that socio-economic characteristics of the respondents namely education, land holding, annual income, tenure of work, cosmopoliteness, extension contact, organizational participation, interest in public work and political awareness were positively and significantly related with extent of media use. It was however, observed that characteristics namely, age, major occupation and official position were non-significantly related with the extent of media use by PRI woman members.

The regression analysis revealed that the set of selected twelve independent variables explained 49.17 per cent variation in the extent of media use by the woman members of PRIs.

\section{Implications}

It was observed that the selected independent variables had contributed about 49.00 per cent variation in the extent of media use by the respondents. It means, some other factors are responsible to great extent in determining the 
extent of media use by the PRI woman members. This suggests the need for future studies on the similar lines but with variables other than those included in present study.

\section{References}

Chandrashekhar, B. K. and Inbanthan, Anand (1991).'Profile and participation of Zilla Parishad and Mandal Panchayat Members' A case of Karnatka.Journal of Rural Development.10(5) : 575589.

Jhamtani, Anita ., Singh, Premalata., Sharma, Nishi., and Singh B. (2001). 'Women in panchayats-perceptual roles'. Indian Journal of Extension Education $37: 1-2$.

Kubde,V. R., Kalantri, L. B. and Sarode, L.V.
(1990). 'Background profile of members of Grampanchayats and their opinion about the institution'. Maharashtra Journal of Extension Education.11 : 252-255.

Mulla, Shabana, H. (2006). 'A study of role perception and performance of the women members of grampanchayat from Hatkanagle taluka of Kolhapur district.' M.Sc (Agri) Thesis, Mahatma Phule Krishi Vidyapeeth, Rahuri (MS).

Pujari, Varsha. (2006). 'A study on training needs of Panchayat women members in Ratnagiri district,' M. Sc. (Agri.) Thesis, Dr. Balasaheb Sawant Konkan Krishi Vidyapeeth, Dapoli, Dist. Ratnagiri (MS).

\section{How to cite this article:}

Kanase Pallavi. S., R. B. Kalamkar, S. S. Shende and K. V. Chorge. 2020. Relationship Between Socio-Economic Profile and Extent of Media Use by Woman Members of Panchayat Raj Institutions (PRIs). Int.J.Curr.Microbiol.App.Sci. 9(07): 3852-3858. doi: https://doi.org/10.20546/ijcmas.2020.907.451 